J. Perinat. Med. 14 (1986) 123

\section{Neonatal jitteriness of unknown origin and circulating catecholamines}

\author{
Maureen Sims ${ }^{1}$, Raul Artal ${ }^{2}$, Hung Quach', and Paul Y. K. Wu ${ }^{1}$
}

${ }^{1}$ Neonatology Division, Department of Pediatrics, and the ${ }^{2}$ Division of Maternal-Fetal Medicine, Department of Obstetrics and Gynecology, University of Southern California School of Medicine and the Los Angeles CountyUniversity of Southern California Medical Center, Los Angeles, California, U.S.A.

\section{Introduction}

Jitteriness in the neonate is a clinical condition which is described as a symmetrical coarse tremor of low amplitude and high frequency. Sometimes the etiology for the jitteriness is found to be secondary to hypoglycemia, hypocalcemia, maternal substance abuse, polycythemia or hypoxic-ischemic encephalopathy [6]. Often the cause, however, cannot be determined by history or conventional laboratory assessment and the etiology for the majority of cases of jitteriness remains unclear. Two possible causes which have not been evaluated for jitteriness in the neonate, but have been recognized as being capable of producing states of neuronal hyperexcitability are brain injury [6] and elevated catecholamine levels [2]. The purpose of this study is to determine if brain injury, or elevated circulatory levels of catecholamines may be associated with neonatal jitteriness.

\section{Methods}

Jitteriness was defined as a generalized and symmetric movement disorder with a coarse tremor which can be diminished effectively by gentle passive flexion.

\section{Curriculum vitae}

MAUReen Sims, M.D., was born in Connecticut and graduated from Boston University Medical School. She completed a pediatric residency and a perinatalneonatal fellowship at the Los Angeles County University of Southern $\mathrm{Ca}$ lifornia Medical Center, where she is currently Assistant Professor of Pediatrics, in the Neonatology Division. Her main interests are apnea and neonatal intracranial hemorrhage.

At the Los Angeles County-University of Southern California Medical Center, all jittery infants are routinely evaluated for hypoglycemia, hypocalcemia, hypomagnesemia, polycythemia and electrolyte imbalance. Any jittery infant who demonstrated any of these disorders, who had evidence of perinatal asphyxia and/or depression as assessed by Apgar scores of $<7$ or had a history of maternal substance abuse were excluded. Blood was drawn by venapuncture on all infants. All aspects of the study were reviewed and approved by the 
Human Subjects Committee of the University of Southern California School of Medicine and informed consents were obtained. The infants were separated into two groups depending on the presence of jitteriness.

Group A was comprised of thirteen infants who had jitteriness as their only presenting sign. Jitteriness was detected at a mean postnatal age of $1.08 \pm 0.2$ days. Hematocrit and serum glucose, calcium, phosphate, magnesium, sodium, potassium, and plasma catecholamine levels were determined at a mean age of $1.27 \pm 0.4$ days of life. Cranial ultrasonography was performed on all infants.

Group B was comprised of twenty-one infants who were clinically normal and served as the control group. Blood sampling was done at $1.3 \pm 0.2$ days of life for the same determinations as in Group A. Cranial ultrasonography was obtained in sixteen of the twenty-one infants.

Cranial ultrasonography was performed with an ATL ultrasound scanner in three coronal and three saggital views on 29 of the studied patients. The images were permanently recorded. The scans were evaluated for the presence of intracranial hemorrhage, which occurs when significant cerebral blood flow disturbance exists and is considered a good marker for cerebral injury in the neonate [6].

Plasma catecholamines were determined by a modified microenzymatic radioenzymatic assay [5]. Sensitivity of the assay was 15 picograms per $\mathrm{ml}$. for both norepinephrine and epinephrine. Determinations were done in one assay to avoid assay variability.

\section{Results}

The groups were comparable in gender, birthweight, gestational age, Apgar scores and route of delivery (table I). The core temperatures in both groups were normal and comparable at birth and at the time of the study. There were no differences found in the hematocrits, or serum glucose, calcium, magnesium, sodium,
Table I. Study population.

\begin{tabular}{lll}
\hline Number & $\begin{array}{l}\text { Jittery } \\
\text { group 13 }\end{array}$ & $\begin{array}{l}\text { Control } \\
\text { group 21 }\end{array}$ \\
\hline Birthweight (g)* & $3394 \pm 335$ & $3298 \pm 902$ \\
Gestational age (wk)* & $40.3 \pm 1.0$ & $40.0 \pm 1.5$ \\
$\begin{array}{l}\text { Apgar 1 min** } \\
\text { Apgar 5 min** }\end{array}$ & 8 & 8 \\
$\begin{array}{l}\text { Route of delivery } \\
\text { c-section/vaginal }\end{array}$ & 9 & 9 \\
\hline
\end{tabular}

* mean $\pm \mathrm{Sd}$

** median

Table II. Laboratory values.

\begin{tabular}{lcc}
\hline Number & $\begin{array}{l}\text { Jittery } \\
\text { group 13 }\end{array}$ & $\begin{array}{l}\text { Control } \\
\text { group 21 }\end{array}$ \\
\hline HCT \% & $51.6 \pm 7.6$ & $51.0 \pm 7.1$ \\
Se glucose (mg/dL) & $55.8 \pm 17$ & $53.5 \pm 14$ \\
Se Ca (mg/dL) & $9.0 \pm 1.0$ & $9.0 \pm 0.6$ \\
Se Mg (mg/dL) & $2.8 \pm 0.2$ & $2.8 \pm 0.2$ \\
Se Na (mEq/L) & $139 \pm 2.7$ & $140 \pm 3.9$ \\
Se K (mEq/L) & $4.9 \pm .8$ & $4.8 \pm .48$ \\
Se P (mg/dL) & $6.9 \pm 1.4$ & $7.2 \pm .86$ \\
Epinephrine (pg/ml) & $909 \pm 682$ & $735 \pm 514$ \\
Norepinephrine $(\mathrm{pg} / \mathrm{ml})$ & $1276 \pm 574$ & $914 \pm 338 *$ \\
\hline
\end{tabular}

$* \mathrm{p}<.05$

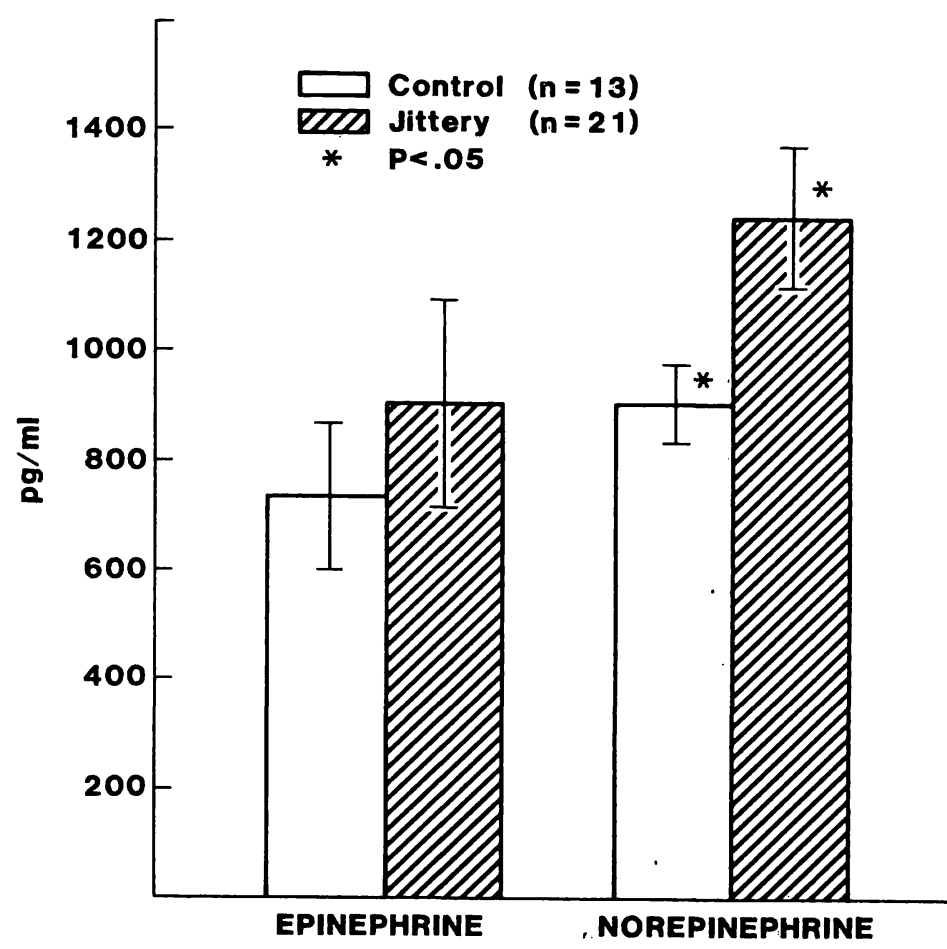

Figure 1. Comparison of norepinephrine and epinephrine levels in jittery and control neonates. 
potassium, or phosphate (table II). Cranial ultrasonography was normal on all patients scanned. The plasma norepinephrine level, however, was found to be significantly elevated in the jittery group of infants compared to the control group (figure 1).

\section{Discussion}

The data from this study indicate that jitteriness is not related to brain injury, but is associated with an elevated norepinephrine level. The reason for this elevation is unclear. Norepinephrine has been identified as the major catecholamine released at birth [1], and perhaps the exaggerated levels in the jittery neonate is part of the same process of neonatal adaptation to extrauterine life. Elevation of norepinephrine also has been recognized in cold stressed neonates as part of their unique process of nonshivering thermogenesis. It was not possible in this study to determine if a thermoregulatory disturbance induced the elevated levels of norepinephrine since temperature gradients were not determined. Raised levels of norepinephrine also have been found to be associated with increased skeletal muscle activity $[2,3,4]$.

It is not possible from this study to identify a mechanism by which norepinephrine is raised in the jittery neonate or determine a cause and effect relationship. We conclude that jitteriness is not secondary to intracranial hemorrhage, but is related to increased sympathetic activity. What influence the increased levels have on other metabolic and hormonal systems is yet to be determined.

\section{Summary}

Jitteriness is a common problem affecting neonates. Although the cause can sometimes be determined by history or conventional laboratory evaluations, nevertheless, in many instances the cause of the jitteriness is unknown. To determine if either intracranial hemorrhage (ICH) or elevated catecholamines are responsible for jitteriness in neonates, we studied 34 healthy term neonates with normal hematocrits, serum glucose, $\mathrm{Ca}, \mathrm{Mg}, \mathrm{Na}, \mathrm{K}$ and P. Thirteen of the infants had jitteriness as their only clinical problem. There were no differences in Apgar scores, birthweight, or gestational age in the two groups. Norepinephrine levels were significantly elevated in the jittery group as compared to the control group: $1276 \pm 574$ vs. $914 \pm 338, p<0.05$. Epinephrine levels were not different in the two groups. Intracranial hemorrhage was not found in any of the patients.

Jittery neonates have increased sympathetic activity. What influence the increased levels have on other metabolic and hormonal systems is yet to be determined.

Keywords: Catecholamine, intracranial hemorrhage, neonatal jitteriness, norepinephrine.

\section{Zusammenfassung}

Tremor unbekannter Ursache beim Neugeborenen und zirkulierende Katecholamine

Ein Tremor ist ein häufig zu beobachtendes Symptom beim Neugeborenen. Manchmal kann die Ursache durch Anamnese oder über laborklinische Parameter geklärt werden; in vielen Fällen ist die Genese jedoch unbekannt. Um zu bestimmen, ob eine intrakranielle Blutung (ICH) oder eine erhöhte Katecholaminkonzentration Ursache des neonatalen Tremors ist, untersuchten wir 34 am Termin geborene Kinder mit normalen Hämatokrit-, Blutzucker-, $\mathrm{Ca}^{++}, \mathrm{Mg}^{++}, \mathrm{N}^{+}, \mathrm{K}^{+}$- und Phosphatwerten. Bei 13 Kindern war der Tremor das einzige klinische Symptom. In Bezug auf den Apgar-Score, das
Geburtsgewicht und das Schwangerschaftsalter gab es zwischen dem Untersuchungskollektiv und der Kontrollgruppe kcine Unterschiede.

Der Noradrenalinspiegel war in der Gruppe mit Tremor signifikant erhöht im Vergleich zur Kontrollgruppe: $1276 \pm 574$ versus $914 \pm 338, p<0.05$. Die Adrenalinspiegel unterschieden sich nicht. Eine intrakranielle Blutung wurde bei keinem der Ncugeborenen diagnostiziert. Neugeborene mit Tremor haben cine erhöhtc Sympathikus-Aktivität. Es muß untersucht werden, in welcher Weise dadurch andere metabolische und hormonelle Systeme beeinflußt werden.

Schlüsselwörter: Intrakranielle Blutung, Katecholamine, Noradrenalin, Tremor beim Neugeborenen. 


\section{Résumé}

Convulsions néo-natales d'origine inconnue et catécholamines circulantes

Les convulsions sont un problème courant affectant les nouveaux-nés. Dans de nombreux cas, la cause des convulsions est inconnue, même si celle-ci peut parfois être déterminée par l'histoire ou les examens courants de laboratoire.

Nous avons étudié 34 nouveaux-nés en bonne santé, à terme, avec hématocrite, glycémie, $\mathrm{Ca}, \mathrm{Mg}, \mathrm{K}$ et $\mathrm{P}$ normaux, pour déterminer si soit l'hémorragie intracranienne (HIC) soit l'élévation des catécholamines sont responsables de convulsions chez le nouveau-né.

Treize enfants ont présenté des convulsions comme seul problème clinique. Il n'y avait pas de difference dans les scores d'Apgar, le poids de naissance, ni l'âge gestationel dans les deux groupes.

Les taux de norepinephrine étaient élevés de façon significative dans le groupe avec convulsions en comparaison du groupe contrôle: $1276 \pm 574$ versus $914 \pm 338$.

Les taux d'épinephrine n'étaient pas differents dans les deux groupes. Il n'a pas été trouvé d'hémorragie intracranienne chez les patients.

Les nouveaux-nés qui convulsent ont une activité sympathique accrue. Il reste encore à déterminer quelle influence ont les taux élevés sur les autres systèmes métaboliques et hormonaux.

Mots-clés: Catécholamines, convulsions néo-natales, hémorragie intra-cranienne, norepinephrine.

\section{References}

[1] Artal R, RW Lam, Y Eliot, CJ Hobel, DA FishER: Circulating catecholamines prior to and after delivery. In: UsDIN E (ed): Catecholamines: Basic and Clinical Frontiers. Vol I. Pergamon Press, Oxford-London 1979

[2] Bowman WC, MW Notr: Actions of sympathomimetic amines and their antagonists on skeletal muscle. Pharmacol Rev 21 (1969) 27

[3] Bowman WC, C RAPER: Effects of sympathomimetic amines on neuromuscular transmission. $\mathrm{Br} \mathrm{J}$ Pharmacol 27 (1966) 313

[4] Karlberg LC, JP Gallagher: The facilitatory effects of catechol and phenol at the neuromuscular junction of the cat. Neuropharmacology 10 (1971) 153
[5] Peuler DJ, G Johnson: Simultaneous single isotope radioenzymatic assay to plasma norepinephrine, epinephrine and dopamine. Life Sci 21 (1977) 625

[6] VolPE JH: Neurology of the Newborn. WB Saunders Company, Philadelphia 1981

Received March 15, 1985. Revised May 23, 1985. Accepted June 10, 1985.

Maureen E. M. Sims, M. D.

Los Angeles County - USC

Medical Center

Women's Hospital L-919

1240 Mission Ave.

Los Angeles, CA 90033, U. S. A. 